\title{
Analysis of the Effectiveness of Zakat Distribution at the Amil Zakat Institution Initiative Zakat Indonesia (LAZ IZI)
}

\author{
Efri Syamsul Bahri ${ }^{1}$, Mohd Mizan Mohammad Aslam ${ }^{2}$, Amran Muhammad ${ }^{3}$ \\ \{efri.sb@sebi.ac.id ${ }^{1}$, m.mizan@unimap.edu.my²,amran.muhammad@aeu.edu.my ${ }^{3}$ \} \\ Asia e University \& Sekolah Tinggi Ekonomi Islam SEBI ${ }^{1}$, University Malaysia Perlis (UNIMAP), \\ Malaysia $^{2}$, Asia e-University, Malaysia ${ }^{3}$
}

\begin{abstract}
Law Number 23 the Year 2011 regarding Zakat Management mandates that the purpose of Zakat management is to increase the benefits of Zakat in order to realize social welfare and poverty alleviation. One of the Amil Zakat Institutions (LAZ), which is active and accomplished in realizing Zakat management's objectives, is LAZ Initiative Zakat Indonesia (LAZ IZI). This study aims to measure the effectiveness of distributing Zakat, Infaq/Alms, and Other Religious Social Funds (ZIS and DSKL) at LAZ IZI. This research uses quantitative methods with a descriptive approach. Measurement of effectiveness is done using the Allocation to Collection Ratio (ACR) formula based on Zakat Core Principles (ZCP). The object used in this study is the LAZ IZI financial statements for the period 2016 to 2019. Based on the ZCP, the level of distribution effectiveness during the four years of operation is $92 \%$ or included in the High Effective category, where Allocation to Collection Ratio $(\mathrm{ACR}) \geq 90$ percent. It means that ZIS and DSKL funds are distributed to mustahiq in a high-effective manner. The results of this study suggest that LAZ IZI can maintain the level of effectiveness of Zakat distribution with an ACR ratio above $90 \%$ so that it remains in the High-Effective category.
\end{abstract}

Keywords: effectiveness of disbursement, ACR, Zakat Core Principle

\section{Introduction}

According to Puskas (2019) research results, [1], the potential amount of Zakat in Indonesia reaches IDR 233.8 trillion, with details in Figure 1. Zakat's potential is equivalent to 1.72 percent of the Gross Domestic Product (GDP) in 2017. While the realization is (Azzahra \& Majid, 2020) reached $3.46 \%$ or IDR 8.1 trillion. Therefore, it is essential to optimize Zakat management, which consists of The Nastional Board of Zakat (BAZNAS), Provincial BAZNAS, Regency/City BAZNAS, and Amil Zakat Institution (LAZ), in the hope that muzaki trust will increase [2].

Optimize the potential of Zakat, the government has given the mandate BAZNAS to coordinate the management of Zakat nationally in Indonesia. As a coordinator, the role of BAZNAS is a significant change in zakat regulation in Indonesia from Law no. 38/1999 became Law no. 23/2011 [3]. The role of BAZNAS, apart from being a coordinator, is also an operator in managing zakat [4]. The role of BAZNAS as a coordinator is to provide recommendations to the Amil Zakat Institution (LAZ) to ensure that LAZ to collect zakat funds and other socioreligious funds can be accounted for [5], become a reporting center for zakat management in 
Indonesia [6], and become the principal capital in monitoring and making regulations [7]. One of them is the regulation related to the distribution activities of Provincial/District/City BAZNAS and LAZ to keep the ratio of distribution to the collection in an Effective position based on the assessment of Core Principle Zakat (ZCP).

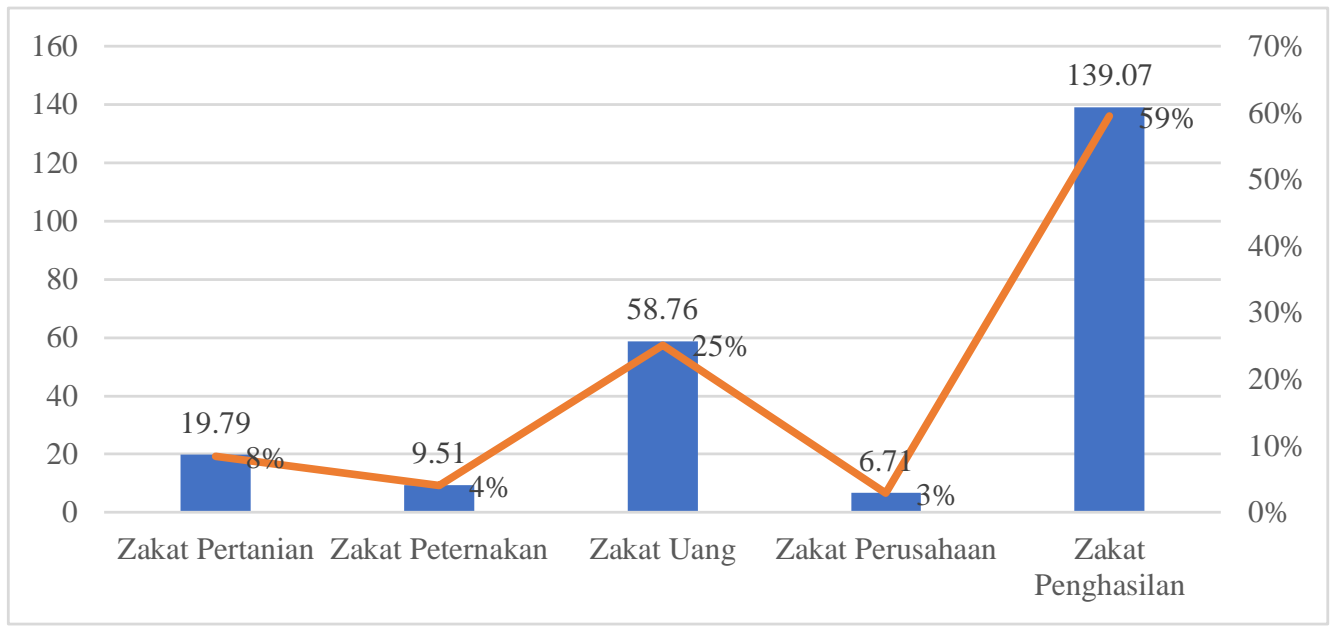

Fig. 1. Potential of Zakat in Indonesia. Source: [8], [1], processed

Law No.23 of 2011 concerning Zakat Management mandates two objectives of Zakat management. First, to increase the effectiveness and efficiency of services in managing Zakat. Second, increasing the benefits of Zakat for realizing people's welfare and poverty alleviation. [9], [10], [11]

One way to determine the level of effectiveness of Zakat management is to use the Allocation to Collection Ratio (ACR) formula. ACR is the ratio between the proportion of Zakat funds distributed and the Zakat funds raise [12]. The purpose of ACR is to measure a Zakat institution's ability to distribute its Zakat funds by dividing the total distribution funds by the total funds raised [9].

It is essential to measure the effectiveness of Zakat. According to [13], the effectiveness of Zakat can have an incredible impact on the mustahiq. The effective distribution of Zakat can reduce poverty significantly [14]. Along with the increasing effectiveness of Zakat management, trust, quality, and credibility will also increase, which will significantly affect muzaki preferences in paying Zakat [15]. Thus, better Zakat management can increase muzaki trust in Zakat management organizations [2].

Research on the effectiveness of Zakat distribution has been conducted before on the National Zakat Agency (BAZNAS) and Rumah Zakat. The results of ACR measurement against BAZNAS using the Zakat Core Principle (ZCP) formula show that the level of distribution effectiveness for 18 years of operation is $90 \%$ (ninety percent) with the Very Effective category where the Allocation to Collection Ratio (ACR) reaches $\geq 90$ percent [9]. Furthermore, the ACR measurement results for Rumah Zakat with a distribution effectiveness level of $87 \%$ or included in the Effective category, where the Allocation to Collection Ratio (ACR) reaches 70-89\% percent in the significant category [10].

Meanwhile, the ACR measurement carried out by [16] on the Indonesian Zakat Initiative Amil Zakat Institute (LAZ IZI) was only carried out for 2016, 2017, and 2018. The ACR measurement results against LAZ IZI show that the level of effectiveness of distribution at LAZ 
IZI in 2016 was $51 \%$; in 2017, the score was $92 \%$, and in 2018 the score was $96 \%$. The increase in the ACR ratio, in 2018, LAZ IZI [17] received appreciation from the Ministry of Religion as the Best LAZ in 2018. This award is given for LAZ IZI's ability to innovate and develop Zakat science's world to answer the challenges of the times and methods that facilitate society.

In fact, in 2019, the BAZNAS Strategic Studies Center assessment results showed that LAZ IZI achieved the highest National Zakat Index value in 2019 with a value of 0.87 . Therefore, based on the description above, we are interested in measuring the ACR LAZ IZI in the 2016-2019 period to determine the level of effectiveness of distribution for four years from 2016-2019 with the title of the research is "Analysis of the Effectiveness of Zakat Distribution at the Amil Zakat Institution Initiative Zakat Indonesia (LAZ IZI)." From this research, it is hoped that it can contribute to the development of science, develop research methodologies, and increase the effectiveness of Zakat distribution to other Zakat managers, including BAZNAS, Provincial BAZNAS, Regency/City BAZNAS, and LAZ.

\section{Literature Review}

\subsection{Definition of Zakat}

The word Zakat means al-barakatu (blessings), an-namaa (growth and development), aththaharatu (holiness), and ash-shalahu (success) (Dhaif, 2011), Hafidhuddin (2002), [18], blessings, clean, developed and useful [9]. Furthermore, the meaning of Zakat according to the term is a certain amount of property which is obliged by Allah to be handed over to the person entitled to receive it, in addition to means spending a certain amount itself (Qardhawi; (Deni Lubis, 2018), is given to those who have the right to receive it according to the provisions stipulated by Islam which according to Ibn Taymiyyah, the hearts and assets of those who pay Zakat become pure and clean and develop meaningfully (Chaniago, 2015), [9].

In terms of regulation, according to Law No.23 of 2011 concerning Zakat Management, Zakat is a property that must be issued by a Muslim or a business entity to be given to those entitled to receive it following Islamic law. Furthermore, Zakat is a religious obligation [19], which is classified as one of the five pillars of Islam [20], the third pillar of Islam [21], is considered the purification of acquired property [22], one of the pillars of Islam with a socioeconomic pattern [5].

\subsection{Disbursement of Zakat}

Zakat funds that have been collected are then distributed to mustahiq [19], with the category of eight asnaf following Surah At-Taubah [23]. In BAZNAS Regulation No.3 of 2018 concerning Distribution and Utilization, it is explained that Zakat distribution includes two areas, namely: distribution and utilization. Distribution is defined as the distribution of Zakat to mustahiq in the consumptive form. At the same time, utilization is the optimal use of Zakat without reducing its value and usefulness in the form of productive business so that it is useful to achieve the ummah benefit [9].

ZIS and DSKL funds that are distributed to distribution programs are expected to be able to cover all the needs of the people and the interests of the community [24], meet daily needs [25], [26], dihabiskan untuk kebutuhan rumah tangga [27], be spent on household needs [28], meet the basic needs of mustahiq [29].

Meanwhile, ZIS and DSKL funds that are distributed to empowerment programs are used to increase income [30], empowerment efforts [31], [32], alleviate poverty (Sadeq, 1997), [33], 
[34], improve economic life the mustahiq [35], and build mentally independent mustahik so they can turn into muzak [36].

\subsection{Effectiveness of Zakat Disbursement}

Effectiveness comes from the root word effective, with the meaning, according to KBBI, is influence, the effect can bring results or consequences [16]. Effectiveness is the success of achieving the goals previously set (Rifa'i, 2013), [9]. The purpose of evaluating the effectiveness of Zakat distribution is to determine the effectiveness of Zakat distribution. Thus, the management of ZIS and DSKL can be accounted for and can realize good Zakat governance (Susilowati \& Setyorini (2018), [37].

The model for measuring the effectiveness of ZIS and DSKL disbursement can be done using the ACR formula model based on the Zakat Core Principle (ZCP). In this case, ACR illustrates the ability of Zakat institutions to disburse Zakat funds is the ACR ratio. ZCP is a best practice-based Zakat management framework and standards to improve the quality of the Zakat system [37]-[39], which was designed by Bank Indonesia, the National Zakat Agency (BAZNAS), and IRTI-IDB in 2016.

\section{Research Methods}

This study uses qualitative research methods with a literature study [40]. Data and documents were collected from various literature related to this research topic, sourced from journals, articles, books, and proceedings. A literature study [41] includes research where the object of study in the literature. Literature stud (Anjar Wanto, 2019:39); [25] conducted to complement the necessary knowledge and theory in this study. The purpose of the literature study [42] is to find references and theories or propositions that support and relate to this research theme.

This study uses the Allocation to Collection Ratio (ACR) in the Core Principle Zakat (ZCP). Based on the ZCP [9], ACR is obtained by dividing the total funds distributed by the total funds raised. The ACR [43] assessment consists of several categories, with the following details: 1 . Highly Effective (if ACR $\geq 90$ percent) 2. Effective (if ACR reaches 70- 89 percent) 3. Fairly Effective (if ACR reaches 50- 69 percent) 4. Below Expectation (if ACR reaches 2049 percent) 5. Ineffective (if ACR $<20$ percent)..

The object used in this research is the LAZ IZI distribution report for the period 2016 to 2019, where data is obtained from the LAZ IZI website. LAZ was chosen to be the object of this research because it received appreciation from the Ministry of Religion as the Best LAZ in 2018. Measurement of ACR against LAZ IZI has been carried out from 2016 to 2017. To find out the sustainable development, it is necessary to measure ACR for the period 2016 to 2019.

\section{$4 \quad$ Results and Discussion}

\subsection{Profile of LAZ IZI}

LAZ IZI was founded in 2014 and started implementing social programs in 2015 [44]. LAZ IZI became a new entity incorporated as a foundation right on Heroes' Day, 10 November 2014 [45] after the spin-off from its parent organization PKPU, which was initially a Zakat 
management unit to become a new entity [46]. The primary mission of IZI is to focus on encouraging the potential strength of Zakat, donations, and alms (ZIS) to become an essential pillar of the strength of the people in the country and a high commitment to compliance both with regulations and sharia.

IZI's vision is to become a trusted professional Zakat institution that inspires policy and empowerment movements. Meanwhile, there are five missions carried out. First, carrying out the functions of education, information, consultation, and raising Zakat funds. Second, utilizing Zakat funds for mustahiq with the principles of independence. Third, forging partnerships with the community, business world, government, media, academia, and other institutions based on values alignment.

Fourth, manage all organizational processes to run following applicable regulations, good governance, and sharia principles. Fifth, play an active role and encourage the formation of various forums, collaborations, and other essential programs that are relevant to increasing the effectiveness of the role of Zakat management institutions at the local, national, regional, and global levels. The value developed is to make it easier, more comfortable. From the name IZI, the word "easy" appears. Prayers that we pray to the Most Giving Ease will only be realized when we want to make it easier for others so that all matters will always be facilitated. [46]

To optimize the achievement of the vision, mission, and values, LAZ IZI designed an organizational structure consisting of a Board of Trustees, a Board of Directors, a Supervisory Board, and a Sharia Supervisory Board. In detail, the organizational structure can be seen in Fig. 2 below.

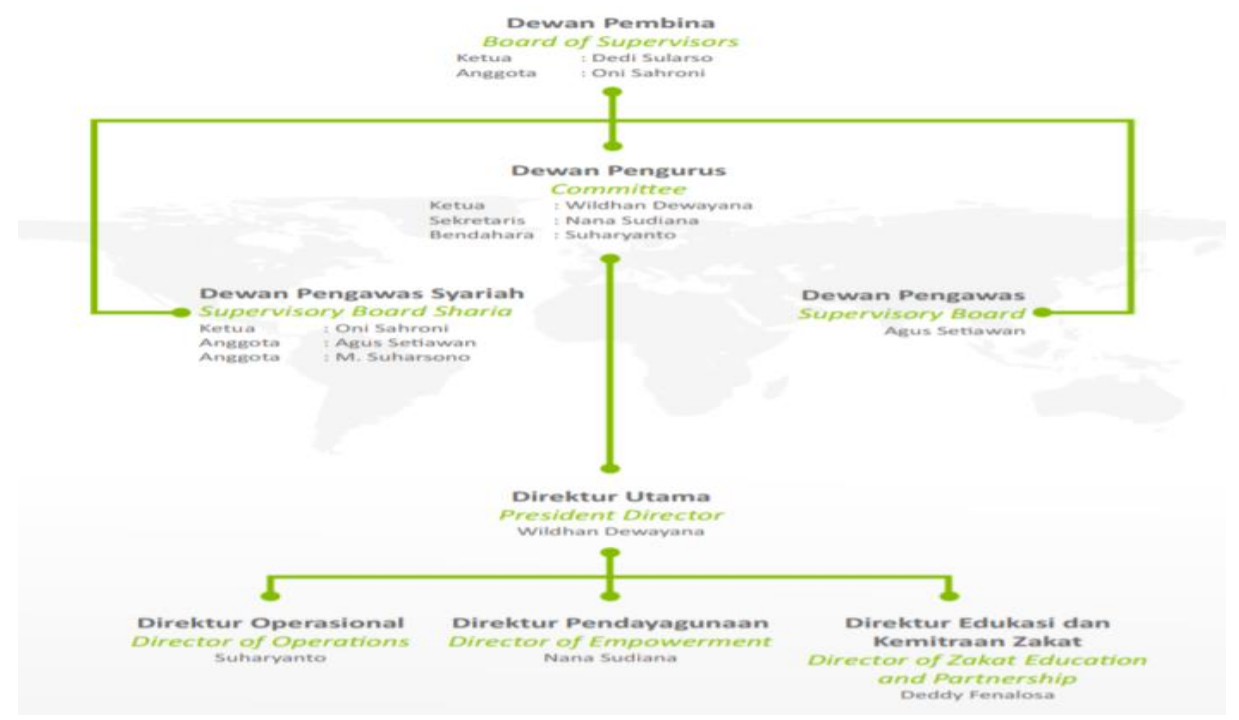

Fig. 2. LAZ IZI Organizational Structure, Source: [45]

During its operation, LAZ IZI won many awards and appreciations, including (1) Achieving the Predicate of Fair Opinion Without Exclusion (WTP) Financial Audit from an Independent Public Accountant Firm 2016-2017, (2) Achieving Accreditation Predicate A in sharia evaluation and audit from Ministry of Religion of the Republic of Indonesia 2018, (3) Achieved the Best LAZ Predicate in West Java Province 2018, and (4) Zakat Manager with the highest national compliance value from the Directorate General of Islamic Community Guidance at the Ministry of Religion of the Republic of Indonesia 2019. 


\subsection{Collection and Distribution Development}

Fund receipts collected by LAZ IZI consist of the receipt of Zakat Funds, Infaq / Alms Funds, Waqf Funds, and Fasum and Bansos Funds. The process of collecting IZI Funds, based on research [47] on one of LAZ IZI's branch offices in Bengkulu City, is carried out through brochures, Zakat education, Zakat outlets, attacks on, banners and billboards. LAZ IZI also optimizes online media [48], and has digital assets, as shown in Fig.3.

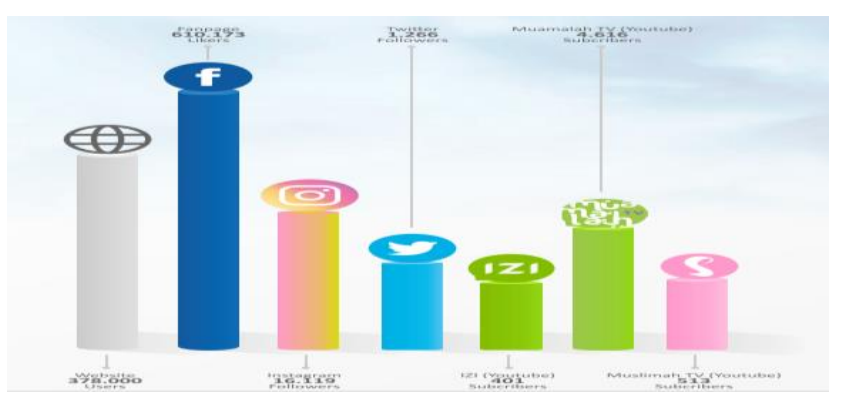

Fig. 2. Digital Asset LAZ IZI. Source: [45]

The total collection of ZIS and DSKL during the 2016-2019 period reached IDR $321,350,782,254.00$. The largest collection occurred in 2018 amounting to IDR $90,906,847,774.00$. Meanwhile, the lowest collection was in the first year of LAZ IZI operation after the PKPU spin-off with the achievement of IDR 69,973,548,817.00. The details are described in Table 1. Thus, the achievement of the highest collection growth at LAZ IZI occurred in 2018, reaching 22.62\%. However, this high growth rate did not continue in 2019. The growth of ZIS and DSKL in 2019 edged up by $0.48 \%$ or increased from Rp90,469,130,362.00 to Rp90,906,847,774.00.

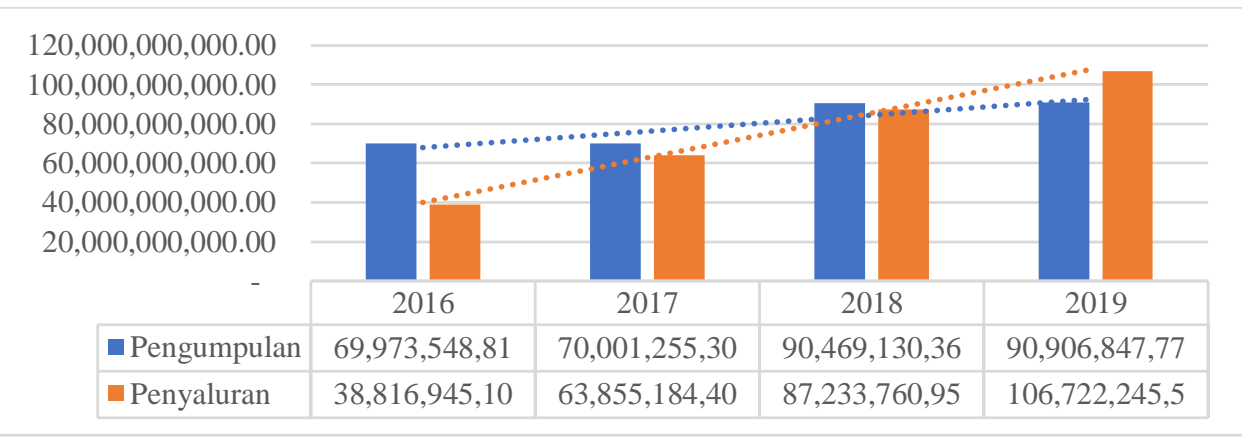

Fig. 4. Collection of Zakat, Infaq/Alms, and Other Religious Social Funds at LAZ IZI for the 2016-2019 Period (In IDR000,-), Source: LAZ IZI Financial Statements, Audited (processed)

From the aspect of distribution, as presented in Figure 4, in the 2016-2019 period, the distribution reached IDR 296,628,136,022.00 with an average amount per year of IDR 74,157,034,005.50. The largest distribution occurred in 2019 reaching IDR $106,722,245,568.00$. Meanwhile, the lowest disbursement occurred in 2016, amounting to IDR $38,816,945,100.00$.

ZIS and DSKL LAZ IZI funds are distributed with the target of eight asnaf and five program areas. The eight mustahiq asnaf, namely: Poor, Poor, Amil, Muallaf, Riqob, Ghorimin, 
Ibn Sabil, and Fii Sabilillah. It is following the provisions of Surah At-Taubah verse 60. Meanwhile, the five program fields consist of economics, education, health, da'wah, and social sectors. The five fields are packaged into five that program: IZI to Success, IZI to Smart, IZI to Fit, IZI to Iman, and IZI to Help.

From the aspect of the number of mustahiq served, it continues to increase from year to year. In 2016, the number of mustahiq beneficiaries served by LAZ IZI only reached 59,470 people. Meanwhile, in 2019 the number of mustahiq served increased by $82 \%$ or reached 108,176 people. The increase in the number of mustahiq beneficiaries was in line with the increase in collection, distribution, and level of effectiveness. It is explained in detail in Fig. 5.

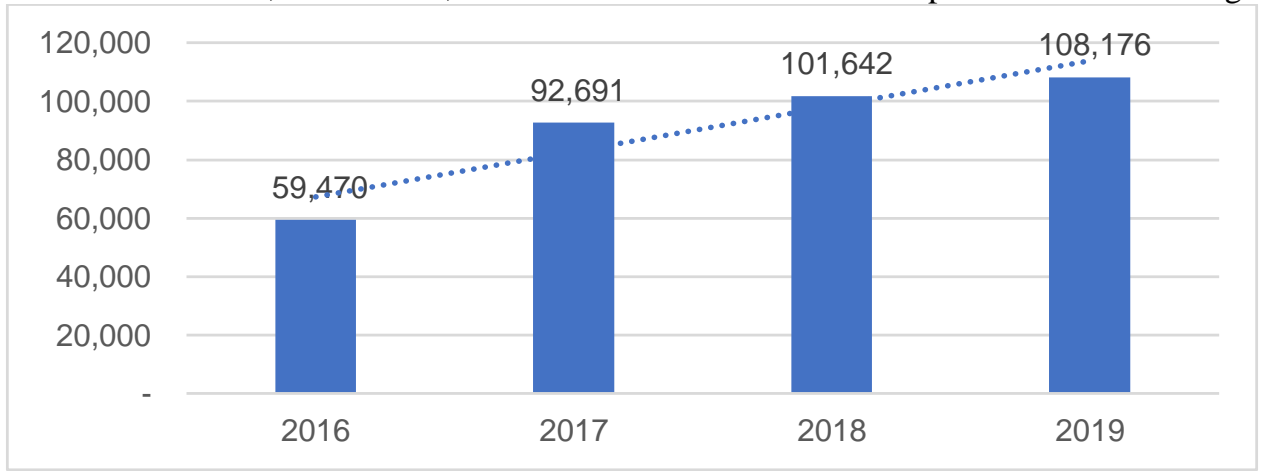

Fig. 5. Number of Mustahiq Beneficiaries (People) for the 2016-2019 Period. Source: [46], [45], processed

\subsection{Effectiveness of LAZ IZI Distribution}

The effectiveness of distribution describes the achievement of Zakat distribution for a certain period, either short, medium, or long term. To optimize Zakat's distribution, Amil Zakat must manage it well by compiling distribution planning, implementation strategies, implementing control, and fair reporting. Thus, mustahiq feel the benefits and blessings of Zakat. The more significant the distribution, the greater the benefits of Zakat felt by the mustahiq.

In the Zakat Core Principle [49], it is explained that to assess Zakat distribution's performance can be seen from the ratio of distribution to the collection of Zakat. The higher the ratio of distribution to Zakat's collection, the more effective the management of Zakat. The high level of effectiveness also illustrates that Zakat is well managed and distributed to mustahik. The sooner Zakat is distributed to mustahiq, the better. Therefore, the method and time limit of distribution needs to be a concern for Amil Zakat.

Measurement of BAZNAS Zakat distribution's effectiveness level in this study is carried out using the Zakat Core Principles (ZCP) method, namely: the effectiveness ratio of the absorption of Zakat funds or called the Allocation to Collection Ratio (ACR). The ACR ratio aims to measure a Zakat institution's ability to distribute its Zakat funds by dividing the total disbursement funds by the total funds raised. Following the ACR method, the level of effectiveness is divided into the following categories: 1. Highly Effective (if ACR $\geq 90$ percent) 2. Effective (if the ACR reaches 70-89 percent) 3. Fairly Effective (if the ACR reaches 50- 69 percent) 4 Below Expectation (if ACR reaches 20-49 percent) 5. Ineffective (if ACR <20 percent). 


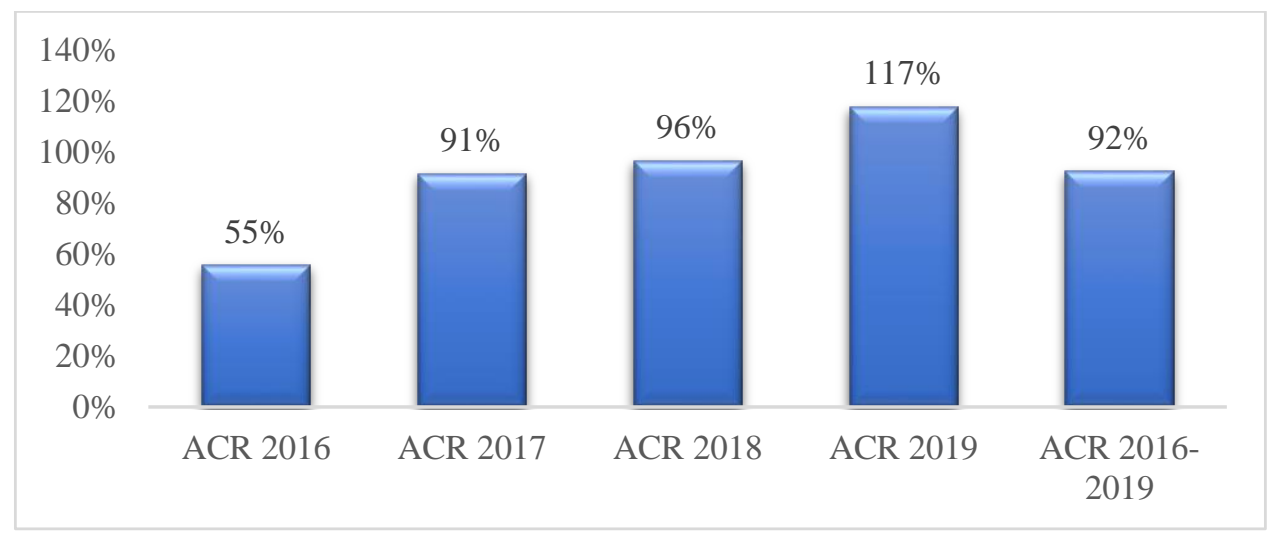

Fig. 6. Hasil Pengukuran Rasio Allocation to Collection Ration (ACR) LAZ IZI

Periode Tahun 2016-2019. Source: LAZ IZI Financial Statements, Audited (processed)

Based on the ZCP, the level of distribution effectiveness for four years with the period 2016-2019 reached $92 \%$ or included in the Highly Effective category, ACR $\geq 90$ percent. The lowest level of distribution effectiveness in 2016 reached 55\%. The level of effectiveness of LAZ IZI distribution continues to increase in succession with the achievement of $91 \%$ (2017), $96 \%$ (2018). In fact, in 2019, it was able to reach $117 \%$. Thus, the level of effectiveness of distribution for four years was able to reach $92 \%$..

Increasing the ACR, of course, will provide a perfect space to raise more ZIS and DSKL Funds. It is hoped that an increase in the ACR ratio can contribute to the interest and trust of muzaki in LAZ IZI. Thus, the benefits of Zakat are increasingly felt by mustahiq as the goal of Zakat management.

\section{Conclusion}

This study's results indicate that the total collection of ZIS and DSKL at LAZ IZI for the 2016-2019 period reached IDR 321,350,782,254.00 with an average annual collection of IDR 80,337,695,563.50. Meanwhile, the amount of ZIS and DSKL distribution to LAZ IZI for the 2016-2019 period reached IDR 296,628,136,022.00 with an average per year of IDR $74,157,034,005.50$. The distribution of ZIS and DSKL includes eight asnaf following the provisions in Surah At-Taubah verse 60, namely: Fakir, Poor, Amil, Muallaf, Riqob, Ghorimin, Ibnu Sabil, and Fii Sabilillah. Meanwhile, the five program areas consist of economics, education, health, preaching, and social activities, packaged into five programs: IZI to Success, IZI to Smart, IZI to Fit, IZI to Iman, and IZI to Help. The number of mustahiq beneficiaries for the four years 2016-2020 reached 361,979 people.

Based on the ZCP, the level of distribution effectiveness in the four years 2016-2020 with an ACR ratio of $92 \%$ or included in the High-Effective category, where ACR $\geq 90$ percent. That is the distribution of High-Effective ZIS and DSKL. This research suggests that LAZ IZI can maintain distribution effectiveness with an ACR ratio of $\geq 90$ percent, in the Highly-Effective category. 


\section{References}

[1] E. S. Bahri and Z. Arif, "Policy Analysis of Zakat Profession in Indonesia," Test Eng. Manag., vol. 83, no. May-June, pp. 29059-29067, 2020.

[2] B. R. Hakim, “Analisis Terhadap Undang-Undang Nomor 23 Tahun 2011 Tentang Pengelolaan Zakat (Perspektif Hukum Islam)," Syariah J. Huk. dan Pemikir., vol. 15, no. 2, pp. 155-166, 2016, doi: 10.18592/syariah.v15i2.552.

[3] S. Nurhasanah, "Akuntabilitas Laporan Keuangan Lembaga Amil Zakat Dalam Memaksimalkan Potensi Zakat," Akuntabilitas, vol. 11, no. 2, pp. 327-348, 2018, doi: 10.15408/akt.v11i2.8826.

[4] M. I. A. Aziz and H. Susetyo, "Dinamika Pengelolaan Zakat Oleh Negara Di Beberapa Provinsi Di Indonesia Pasca Undang-Undang Nomor 23 Tahun 2011," J. Huk. Pembang., vol. 49, no. 4, p. 968, 2020, doi: 10.21143/jhp.vol49.no4.2352.

[5] A. Satori Ismail et al., Fikih Zakat Kontekstual Indonsia. BAZNAS, 2018.

[6] D. Firstiana, "Analisis Indeks Kemiskinan dengan Menggunakan Pendekatan FGT INdex sesudah Program Ikhtiar (Studi Kasus : Program Ikhtiar Masyarakat Mandiri di Desa Tegal dan Desa Babakan Sabrang, Kecamatan Ciseeng, Kabupaten Bogor),” Media Ekon., vol. 20, no. 1, p. 63, 2017, doi: 10.25105/me.v20i1.777.

[7] BAZNAS, Statistik Zakat Nasional 2017. BAZNAS, 2017.

[8] Puskas BAZNAS RI, Indikator Pemetaan Potensi Zakat (IPPZ). Puskas BAZNAS, 2019.

[9] E. S. Bahri and S. Khumaini, “Analisis Efektivitas Penyaluran Zakat pada Badan Amil Zakat Nasional," Al Maal J. Islam. Econ. Bank., vol. 1, no. 2, p. 164, 2020, doi: 10.31000/almaal.v1i2.1878.

[10] E. S. Bahri and Z. Arif, "Analisis Efektivitas Penyaluran Zakat pada Rumah Zakat," Al Maal J. Islam. Econ. Bank., vol. 2, no. 1, p. 13, 2020, doi: 10.31000/almaal.v2i1.2642.

[11] I. F. Hikmah and A. Shofawati, "Tge Efficiency Analysis of 7 National Zakat Management Organizations (OPZ) Using Data Envelopment Analysis (DEA)," J. Ekon. Syariah Teor. dan Terap., vol. 7, no. 6, pp. 1178-1192, 2020, doi: 10.20473/vol7iss20206pp1178-1192.

[12] A. Yudhira, "Analisis Efektivitas Penyaluran Dana Zakat, Infak dan sedekah Pada Yayasan Rumah zakat," J. Ilm. akutansi Keuang. dan bisnis, vol. 1, no. 1, pp. 1-15, 2020.

[13] P. BAZNAS, Dampak Zakat Terhadap Kesejahteraan Mustahik Evaluasi Program Zakat Produktif 2018, vol. 57. 2019.

[14] M. Bouanani and B. Belhadj, "Does Zakat reduce poverty? Evidence from Tunisia using the Fuzzy Approach,” Metroeconomica, no. November 2018, pp. 1-16, 2020, doi: 10.1111/meca.12304.

[15] F. R. Muslih and I. Noor, "Pengaruh Kepercayaan, Kualitas dan Kredibilitas, dan Transparansi terhadap Preferensi Muzaki dalam Memilih Membayar Zakat Maal melalui Lembaga Amil Zakat (Analisis pada Kecamatan Banyuwangi, Bnayuwangi)," J. Ilm. Mhs. Fak. Ekon. dan Bisnis, vol. 8, no. 2, 2020, [Online]. Available: https://jimfeb.ub.ac.id/index.php/jimfeb/article/view/6551.

[16] M. Burhanudin and R. Indrarini, "Efisiensi dan Efektivitas Lembaga Amil Zakat Nasional," Jesya (Jurnal Ekon. Ekon. Syariah), vol. 3, no. 2, pp. 453-461, 2020, doi: 10.36778/jesya.v3i2.221.

[17] F. Ismanto, "Inisiatif Zakat Indonesia Raih Anugerah LAZ Terbaik 2018," 
Tribbunnews.com, p. 2018, 2018.

[18] N. Triyani, I. S. Beik, and L. M. Baga, "Manajemen Risiko pada Badan Amil Zakat Nasional (BAZNAS)," Al-Muzara'ah, vol. 5, no. 2, pp. 107-124, 2018, doi: 10.29244/jam.5.2.107-124.

[19] D. Muhtada, "Islamic Philanthropy and the Third Sector: The Portrait of Zakat Organizations in Indonesia," Islam. Indones., vol. 1, no. 1, p. 106, 2014, doi: 10.15575/isin.v1i1.43.

[20] I. Rachmawati et al., "A Comparative Study on Zakat Management Law Practices between Malaysia and Indonesia," vol. 2, no. 2, pp. 329-342, 2020.

[21] M. Y. Owoyemi, "Zakat management: The crisis of confidence in zakat agencies and the legality of giving zakat directly to the poor," J. Islam. Account. Bus. Res., vol. 11, no. 2, pp. 498-510, 2020, doi: 10.1108/JIABR-07-2017-0097.

[22] A. Y. Q. Saad and A. M. Al Foori, "Zakat and tax: A comparative study in Malaysia," Int. J. Innov. Creat. Chang., vol. 10, no. 12, pp. 140-151, 2020.

[23] R. Saping, S. P. Nelson, and S. N. S. Obid, "Disclosure Practices and Efforts Toward Proposing I-ZKDI: a Case of Malaysian Religious Non-Profit Organisation," Int. J. Psychosoc. Rehabil., vol. 24, no. 4, pp. 4712-4728, 2020, doi: 10.37200/ijpr/v24i4/pr201571.

[24] Maimun, "Pendekatan Maqashid Al-Syariah terhadap Pendistribusian Dana Zakat dan Pajak untuk Pembangunan Masjid," J. Asas, 2014, [Online]. Available: http://www.ejournal.iainradenintan.ac.id/index.php/asas/article/view/235.

[25] E. S. Bahri, P. Ariwibowo, and H. Robbani, "Productive Zakat on Sharia Perspective and Regulation in Indonesia," J. Lit., vol. 2, no. 1, pp. 66-76, 2020, doi: https://doi.org/10.3701.

[26] E. S. Bahri and R. Oktaviani, "Zakat Produktif Sebagai Modal Kerja Usaha Mikro," Perisai Islam. Bank. Financ. J., vol. 2, no. 2, p. 101, 2019, doi: 10.21070/perisai.v2i2.1686.

[27] Z. Zainuddin and H. Khalid, "Legal Perception of the Community Regarding Productive Zakat and Its Utilization In Makassar," Fiat Justisia, vol. 14, no. 1, p. 71, 2020, doi: 10.25041/fiatjustisia.v14no1.1796.

[28] Jamaluddin, I. Misbach, and A. Wahab, “The Distribution of Zakat Mal Based on Al- ' Adl in Order to Improve The Welfare of The Mustahiqs in The Laznas of Baitul Mal Hidayatullah South Sulawesi," Al-Ulum, vol. 20, no. 1, pp. 233-251, 2020, doi: 10.30603/au.v20i1.1146.

[29] M. Solikhan, "Analisis Perkembangan Manajemen Zakat untuk Pemberdayaan Masyarakat di Indonesia,” J. Ilm. Syiar, vol. 20, no. 01, pp. 46-62, 2020.

[30] A. Widyatama, A. S. Baso, and F. Haq, "The Other Side of Zakat in Poverty Reduction: A Phenomenology Study," Iqtishadia, vol. 13, no. 1, p. 77, 2020, doi: 10.21043/iqtishadia.v13i1.5993.

[31] E. S. Bahri, M. M. A. Aslam, A. A. Hj Hasan, and H. Wibowo, "Maqasid Al-Shariah in Micro-entrepreneurs Development: an Overview," in International Conference of Zakat, 2019, pp. 258-267, doi: 10.37706/iconz.2019.182.

[32] Suarni, "Productive Zakat: Alternatif Solution Empowering Ummah Economy," in Proceeding International Seminar on Islamic Studies, 2019, vol. 1.

[33] A. M. H. A. P. Md, "Integrating financial inclusion and saving motives into institutional zakat practices: A case study on Brunei," Int. J. Islam. Middle East. Financ. Manag., vol. 8, no. 2, pp. 150-170, 2015.

[34] M. M. Akram and M. Afzal, "Dynamic Role of Zakat in Alleviating Poverty: A Case 
Study in Pakistan," Munich Pers. RePEc Arch., vol. 56013, no. 56013, pp. 1-45, 2014, [Online]. Available: http://mpra.ub.uni-muenchen.de/56013/.

[35] S. Zalikha, "Pendistribusian Zakat Produktif Dalam Perspektif Islam," J. Ilm. Islam Futur., vol. 15, no. 2, p. 304, 2016, doi: 10.22373/jiif.v15i2.547.

[36] M. Z. Aminudin and L. P. Hadiningrum, "Pengelolaan ZIS dalam Upaya Meningkatkan Kesejahteraan Masyarakat dan Penanggulangan Kemiskinan (Studi Deskriftif dan Preskriptif di BAZNAS Kabupaten/Kota di Eks-Karesidenan Surakarta)," Ziswaf J. Zakat dan Wakaf, vol. 6, no. 1, pp. 101-113, 2019, doi: 10.21043/ziswaf.v4i1.3037.

[37] I. P. Lenap, E. E. Sasanti, N. K. Karim, and N. K. Sari, "Zakat Disbursement Efficiency Based on Zakat Core Principles in Managing Zakat Funds in Baznas of West Nusa Tenggara Province," J. Akunt. dan Bisnis, vol. 20, no. 1, p. 103, 2020, doi: 10.20961/jab.v20i1.500.

[38] A. S. Rusydiana and I. Firmansyah, "Efficiency versus Maqashid Sharia Index: an Application on Indonesian Islamic Bank," Shirkah J. Econ. Bus., vol. 2, no. 2, 2018, doi: $10.22515 /$ shirkah.v2i2.154.

[39] A. C. Yaacob, S. Mohamed, A. Daut, N. Ismail, and M. A. M. Don, "Zakat Disbursement via Capital Assistance : A Case Study of Majlis Agama Islam Johor," J. Emerg. Econ. Islam. Res., vol. 1, no. 2, pp. 1-19, 2013, doi: 10.1088/17518113/44/8/085201.

[40] Y. Bastiar and E. S. Bahri, "Model Pengkuran Kinerja Lembaga Zakat di Indonesia," ZISWAF J. Zakat dan Wakaf, vol. 6, no. 1, p. 43, 2019, doi: 10.21043/ziswaf.v1i1.5609.

[41] T. Sawarjuwono, "Intellectual Capital: Perlakuan, Pengukuran Dan Pelaporan (Sebuah Library Research)," J. Akunt. dan Keuang., vol. 5, no. 1, pp. 35-57, 2003, doi: 10.9744/jak.5.1.pp.35-57.

[42] D. Mulyani, "Model Sistem Informasi Keuangan Bank Sampah Syariah/Micro Finance," 2016.

[43] Puskas Baznas, Outlook Zakat Indonesia 2018. 2018.

[44] AR Utomo, "Laporan Keuangan Yayasan Inisiatif Zakat Indonesia untuk Tahun yang berakhir 31 Desember 2017 dan 2016 dan Laporan Auditor Independen,” 2018.

[45] IZI, Annual Report 2019 "5 Tahun Bersama Menebar Kebahagiaan.” 2020.

[46] IZI, “Annual Report 2018 "3 Tahun Memudahkan Ummat)," 2018.

[47] A. Cahyadi and Suryani, "Zakat Management Application in IZI (Inisiatif Zakat Indonesia)," J. Dawuh, vol. 1, no. 2, pp. 49-54, 2020, Accessed: Sep. 15, 2020. [Online]. Available: https://siducat.org/index.php/dawuh/article/view/71.

[48] S. D. Ananda, "Pemanfaatan Media Online dalam Program-Program di Lembaga Zakat Inisiatif Zakat Indonesia (IZI)," 2020.

[49] M. Nasir et al., "Rencana Strategis 2016-2020 Badan Amil Zakat Nasional," pp. 1-37, 2018. 